Donald G. Frank

\title{
Sports research \\ Key Web sites to facilitate successful research
}

$\mathbf{T}$ his article focuses on key Web sites for sports research at national and international levels. As the list of sports is extensive, some sports are not represented.

Sports research has become a signi cant activity at colleges and universities. An examination of baseball and steroids, for example, produces articles published in the Journal of Legal Medicine, Journal of the American Medical Association, Lancet, American Journal of Sports Medicine, Physician \& Sports Medicine, Sport in Society, and The Economist. Baseball, in particular, has been a topic of serious research in academe, possibly as a result of the extensive data and information available for the 19th and 20th centuries. Research in other sports has also become serious and rigorous.

\section{Baseball}

Baseball Almanac. The Baseball Almanac provides data on players, teams, and leagues. The highlights of all seasons from 1876 to 2006 are summarized in a History section. A Baseball Historians and Researchers section facilitates research. Access: http://www. baseball-almanac.com.

History of Baseball Web sites. Several Web sites focus on the history of baseball, including the Baseball Archive, History of Baseball, Historic Baseball, History of the World Series, and Graphical History of Baseball. Access: http:// www.baseball1.com/c-history.html, http:// www.archaeolink.com/history_of_baseball.htm, http://www.historicbaseball.com/baseballhistory.html, http://www.sportingnews.com/archives /worldseries, and http://home.istar.ca/ mbein /baseball.html.
The Library and Giamatti Research Center at Baseball's Hall of Fame. This is essentially the national archive for materials on baseball. Books, periodicals, photographs, movies, and other materials are available for serious research. The collection of photographs for the 19th and 20th centuries is extensive. As the photographs have not been digitized, one needs to contact or go to the Library and Giamatti Research Center to examine and use these materials. Access: http://www.baseballhalloffame.org/library.

Major League Baseball. Major League Baseball provides current and historical data for players, teams, and leagues, going back to 1871. Data on the Negro League players, teams, and leagues are not included. Access: http://www.mlb.com.

Negro League Baseball Players Association. The Web site for the Negro League Baseball Players Association is excellent, providing valuable information on players, teams, and leagues. Biographical information is provided for all players. Histories of the various teams, leagues, and ballparks are helpful. Unfortunately, statistical data for the players is limited as these data were not compiled and archived by the teams and leagues. Access: http://www.nlbpa.com.

- Society of American Baseball Research. The Society of American Baseball Research facilitates the study of baseball as related to societal conditions. The society provides educational and historical informa-

Donald G. Frank is a professor at Portland State University, e-mail: frankd@pdx.edu

๑ 2007 Donald G. Frank 


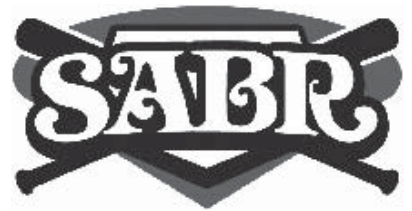

tion on baseball and facilitates research via a series of publications and annual con-

ferences at which scholarly presentations are discussed. Members of the society are able to access databases to obtain full-text articles and other documents. A full-text baseball encyclopedia is available for research. The society maintains an online forum in which scholars discuss numerous issues and topics, including historical details as well as information on patterns and trends. Access: http://www.sabr.org.

\section{Basketball}

Association of Professional Basketball Research. Basketball research is facilitated by the Association of Professional Basketball Research. This Web site provides historical information on players, teams, and leagues, with coverage going back to 1898. A Historical Basketball Statistical Database is extensive and essential for serious research. Access: http://www.apbr.org.

Basketball Reference. Basketball Reference provides statistical data on players, teams, and leagues. The results of all games and data on all players are provided, going back to the 1940s. Access: http://www. basketball-reference.com.

Federation Internationale de Basketball (FIBA). FIBA is the key Web site for basketball at the international level. Information on teams is available for nearly all nations in Africa, Asia, Europe, Oceana, and the Americas. Online forums provide opportunities for dialogues on topics of interest. Archival data and information are limited. Access: http://www. ba.com.

History of Basketball. The History of Basketball is a collection of Web sites providing historical information. Access: http://www. archaeolink.com/history_of_basketball. htm.

National Basketball Association (NBA) and Women's National Basketball Association (WNBA). The Web site of the
NBA focuses on current players, teams, and conditions. Archival information and data are not included. The WNBA Web site provides data on players and teams, with archival data going back to the inception of the WNBA in 1997. Access: http://www.nba.com and http://www.wnba.com.

\section{Football}

National Football League (NFL). An excellent History section is accessible in the NFL s Web site in which one is able to obtain a decade-by-decade chronology of signi cant activities and events from 1869 to the current year. Historical information is available on all NFL teams. Statistical data are available in the Record and Fact Book. Access: http://www.n .com.

Professional Football Researchers Association. Research is supported by a database of full-text articles, a list of books on the history of professional football, and an online forum in which fans and scholars discuss relevant issues. Access: http://www. footballresearch.com.

\section{Hockey}

Hockey Hall of Fame. The Hockey Hall of Fame Web site provides statistical data and informative biographies on every player who has ever appeared in the NHL. A Legends section focuses on the top players. Access: http://www.hhof.com.

Institute for Hockey Research. Scienti c studies of hockey are accessible in the Institute for Hockey Research Web site. Access: http://www.hockeyinstitute.org.

National Hockey League (NHL). The NHL Web site focuses on current players and teams, but also provides a History section. Unfortunately, the historical information is more anecdotal than systematic. Access: http://www.nhl.com.

\section{Soccer/football}

Federation Internationale de Football Association (FIFA). Soccer/football at the international level is covered by FIFA. The FIFA Web site focuses on leagues across 
the globe, with an emphasis on current data. A History of Football section provides several informative reports. Information on the World Cup is also provided. Access. http://www. fa.com/en.

Major League Soccer. The Major League Soccer Web site provides data on players and teams in the United States and includes a History section focusing on the All-Time Leaders. Access: http://www. mlsnet.com.

\section{Tennis}

History of Tennis. Web sites providing historical information are collected in the History of Tennis. Access: http://www. archaeolink.com/history_of_tennis.htm.

United States Tennis Association and ATP Tennis. Current activities and events in professional tennis are covered by the United States Tennis Association and ATP Tennis. ATP provides a Results Archive for all ATP, Grand Slam, and ATP Masters Series events, beginning in 1968. Biographical information is provided for selected players in the ATP. Access: http://www.usta.com and http:// www.atptennis.com.

\section{Golf}

History of Golf. The History of Golf is a collection of Web sites providing historical information. Access: http://www.archaeolink. com/history_of_golf.htm.

Professional Golf Association (PGA) and Ladies Professional Golf Association (LPGA). Professional golf for men and women in the United States is covered by the PGA and the LPGA. Unfortunately, these Web sites provide no archival/historical data or information. Access: http://www.pga.com and http://www.lpga.com.

\section{Stock car racing}

National Association for Stock Car Auto Racing (NASCAR). The NASCAR Web site provides biographical information on key participants (drivers) as well as a Race Archive going back to 2002 for the Nextel Cup Series, the Busch Series, and the Crafts- man Truck Series. NASCAR s History section includes a Daytona 500 archive (1959 2002), annual as well as decade-by-decade reviews (1949 2000), biographies of NASCAR s 50 greatest drivers, a history of the evolution of the stock car, and a summary of great races (1989 2003). Access: http://www. nascar.com.

Research Guide for Stock Car Racing. A Research Guide for Stock Car Racing is accessible at Appalachian State University. The Web site is a gateway to databases; biographies of important people; social and historical information; statistical data; stock car organizations; racing series Web sites; museums, libraries, and halls of fame; and media Web sites. An annotated list of nearly 150 Racing Movies is also included. Access: http://www.library.appstate.edu/reference /subjectguides/stockcar.html.

\section{Collegiate athletics}

National Collegiate Athletics Association (NCAA). Research on athletics on the collegiate level needs to include the NCAA. Information and statistical data are provided for all NCAA sports. Key areas focus on Academics and Athletes, Legislation and Governance, Media and Events, and Sports and Championships. A Research section provides detailed reports on issues such as academic reforms, substance abuse, academic performance and characteristics, graduation rates, international students, revenues and expenses of intercollegiate athletics programs, race/gender demographics, gender/ equity analyses, and the empirical effects of collegiate athletics. Access: http://www. ncaa.org.

NCAA Sports. NCAA activities and events are featured in NCAA Sports. Statistics and History sections are available for the various sports. Access: http://www. ncaasports.com.

\section{Olympic games}

Olympic Movement. The modern Olympic Games are covered by the of cial Web site of the Olympic Movement. A data- 
base provides comprehensive results coverage of the Olympic Summer Games from 1896 to 2004 and the Olympic Winter Games from 1924 to 2006. Biographical information is provided for the Olympic athletes. The Historical Archives are extensive, providing access to numerous full-text documents. More than 20,000 monographs and 250 periodicals are available in the International Olympic Committee Library. Information is also available on the ancient Olympic Games conducted from 776 B.C. to 393 A.D. Access: http://www.olympic.org.

\section{Track and field}

International Association of Athletics Federations (IAAF). IAAF covers track and eld at the international level. Records are provided for of cial events in Asia, Africa, Europe, North America, South America, and Oceania. Several IAAF forums provide opportunities to discuss relevant issues. Access: http://www.iaaf.org.

USA Track \& Field. USA Track \& Field covers activities and events at the professional level for the United States. Biographical information and statistical data are available for current athletes and for Hall of Fame inductees. Access: http://www.usatf.org.

\section{Cycling}

History of Cycling. The History of Cycling is a collection of Web sites providing historical information. Access: http://www.archaeolink.com/history_of_cycling.htm.

United States Cycling Organization \& Union Cycliste Internationale. This site covers the various types of races (road, track, cyclo-cross, BMX), focusing on the participants and results of the races. Access: http://www.usacycling.org and http://www. uci.ch.

\section{Boxing}

International Boxing Hall of Fame. The International Boxing Hall of Fame provides biographical information on all inductees, a series of historical essays on boxing in Legends and Lore, data on all Olympic medalists, a boxing bibliography, and detailed physical characteristics ( tale of the tape ) for all heavyweight champions from John L. Sullivan to the current champion. Access: http://www.ibhof.com.

World Boxing Association. This association oversees boxing on national and international levels. Biographical and historical information is limited, but the WBA Monthly Ratings of boxers in all levels or categories are provided, beginning in 2000. Access: http://www.wbaonline.com.

\section{Sports and Society}

Center for the Study of Sport in Society and Centre for the Sociology of Sport. Various centers and institutes focus on the study of sport in society. The Center for the Study of Sport in Society at Northeastern University and the Centre for the Sociology of Sport at the University of Leicester are representative of these centers and institutes. Access: http://www.sportsinsociety.org and http://www.le.ac.uk/so/css.

North American Society for Sport History. Sports research also encompasses important societal issues. The North American Society for Sport History promotes research on the history of sports and publishes the Journal of Sport History. Access: http://www.nassh.org.

\section{Multi-sport Web sites}

ESPN \& CBS Sportsline. Some Web sites provide data and information on several major sports. ESPN and CBS Sportsline are

\section{Internet resources online}

Internet Resources articles, as printed, are available online at www.ala.org/ala /acrl/acrlpubs/crlnews/internetresources. htm.

A small, but growing, editable collection is also available at wikis.ala.org/acrl/index. php/Internet_Resources_Wiki. 
representative, covering baseball, basketball, football, hockey, soccer, tennis, boxing, automobile racing, collegiate athletics, and other sports. Coverage focuses on current or contemporary issues and teams. Archival or historical data is limited. Extreme sports such as BMX, motocross, inline skating, skateboarding, and snowboarding are covered by ESPN, with a Results Archive of the Summer X Games and the Winter X Games going back to 1998. Access: http://www.espn.com and http://www.cbssportsline.com.

- Sports Network. The Sports Network focuses on current activities and events, but also includes an All-Time Statistics Database for baseball, basketball, and hockey. This database can be downloaded to one s workstation. The database covers baseball from 1871 to 2001, basketball from 1937 to 2001, and hockey from 1917 to 2001. Access: http://www.sportsnetwork.com.

Virtual Library of Sport. The Virtual Library of Sport is an interesting collection of Web sites with an international perspective.
In addition to the major sports noted above, the Virtual Library of Sport also covers sports such as rugby, cricket, snooker, sailing, and darts. Access: http://www.sportsvl.com.

\section{Representative sports blogs}

- Baseball Analysts. Access: http:// www.baseballanalysts.com.

- Baseball Blogs. Access: http://www. baseballblogs.org.

- Basketball Blogs. Access: http://www. basketballblogs.org.

- Football Blogs. Access: http://www. footballblogs.org.

- Hockey Blogs. Access: http://www. hockeyblogs.org.

- NASCAR Blog. Access: http://www. nascarblog.org.

- Soccer Blogs. Access: http://www. soccerblogs.net.

- Sports Blogs. Access: http://www. sportsblogs.org.

- Tennis Blogs. Access: http://www. tennisblogs.org. $\approx$

\section{Elegant Solutions for Preservation}

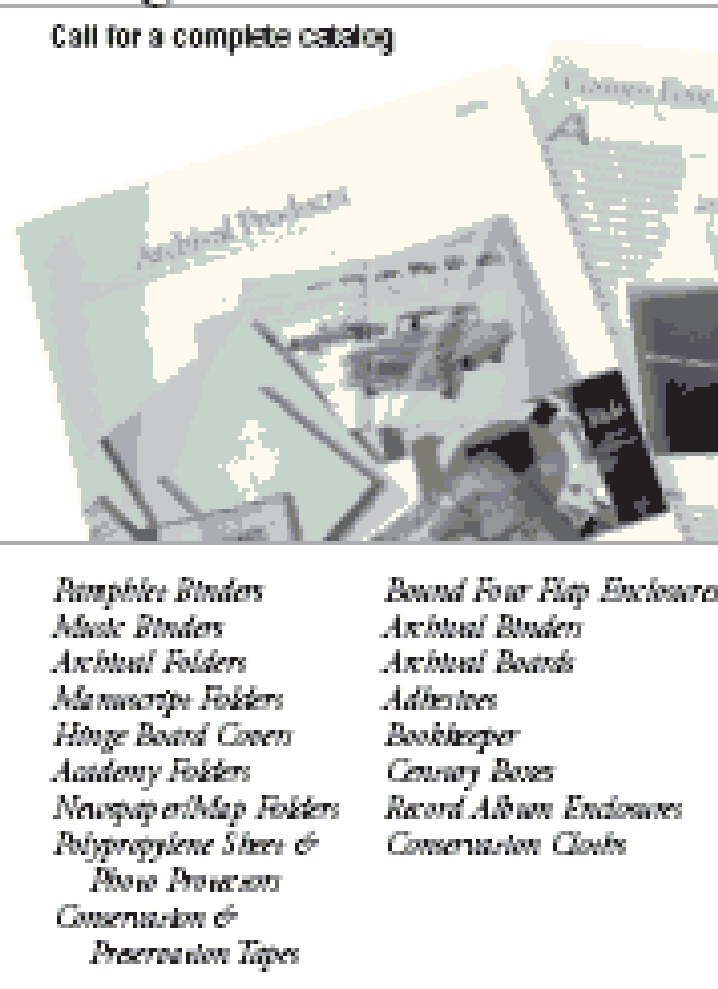

